\title{
Обнадеживающая динамика
}

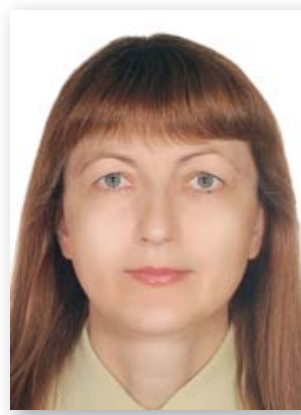

\section{И.А. Гуринович}

Представлена информация об агроклиматических условиях Орловской области и картофелеводстве в регионе, которое в последние годы показывает высокую динамику развития. Производство картофеля преимущественно сосредоточено в центральной и западной зонах области, в меньшей степени - в юго-восточной. В области насчитывается более 10 с.-х. организаций и КФХ, специализирующихся на производстве товарного картофеля. Среди них самые крупные и успешные: AO «Картофельная Нива Орловщины» и КФХ Стебакова В.И.

Ключевые слова: картофелеводство, технология, удобрения, импортозамещение, урожайность.

$\mathrm{B}$ советское время Орловская область была одним из крупнейших картофелепроизводящих регионов в Российской Федерации [1, 2].

В различных объемах, но практически, в каждом хозяйстве, для обеспечения внутренних потребностей, возделывание картофеля считалось нормой. Вплоть до 2000 года в области существовала выстроенная система семеноводства картофеля, производством элитного семенного картофеля занимались такие хозяйства, как ОАО «Звягинки» Орловского района, ГФУП Шатиловская СХОС ВНИИЗБК, ЗАО «Куракинское» Свердловского района, КСП «Богородицкое» Хотынецкого района, ГФУП ОПХ «Орловское» ВНИИЗБК [3]. Сегодня из перечисленных хозяйств лишь ЗАО «Куракинское» Свердловского района занимается производством картофеля, остальные хозяйства перепрофилировались преимущественно на производство зерновых.

Благоприятные природно-климатические условия позволяют получать в нашем регионе высокие урожаи картофеля с хорошими вкусовыми качествами [4].

По климатическим условиям Орловская область относится к переходной, лесостепной зоне, которая занимает промежуточное положение от дерново-подзолистых на северозападе до черноземов разного типа на юго-востоке; тип рельефа - полого-холмистая равнина. По качественному составу пахотные и естественные угодья области представлены разнообразными почвами, среди которых преобладают: подзолистые черноземы - 29,7\%, лесные темносерые почвы - 23,8\%, серые лесные почвы - 23,8\%, выщелоченные черноземы - 12,8\%, светло-серые лесные почвы - 6,8\%, дерново-подзолистые почвы - 1,5\%. Климат области умеренно континентальный, сравнительно теплый, умеренно влажный. Западные и северо-западные районы области по природным условиям близки к лесной зоне, а южные к степной. Область расположена в зоне неустойчивого увлажнения. Годовая сумма осадков по большей части территории области составляет 510-600 мм, местами в центральных районах и на юго-востоке области 440-490 мм.

Производство картофеля преимущественно сосредоточено в центральной и западной зонах области, в меньшей степени-вюго-восточной.

С 1991 года в Орловской области прослеживалась тенденция снижения производства картофеля во всех категориях хозяйств. Резкое сокращение посевных площадей в с.- х. организациях отбросило отрасль на уровень огородничества. Сохранение посадок картофеля в личных подсобных хозяйствах граждан в условиях системного кризиса в АПК - вынужденная мера, источник обеспечения подавляющего большинства семей продовольствием. Около 90\% площадей картофеля находилось в индивидуальном секторе и возделывалось «под лопату», учитывая, что износ картофелеводческой техники и перерабатывающего оборудования достиг $80 \%$ и более.

Сегодня, согласно исследованиям, проведенным Росстат, 4 из 10 горожан в Орле сами выращивают кар- тофель. При этом на селе производством «второго хлеба» заняты 9 из 10 местных жителей.

C учетом личных подсобных хозяйств, на каждого жителя Орловщины в регионе ежегодно производится около 350 кг картофеля [5].

В 2018 году в Орловской области собрано чуть более 274 тыс. т, в том числе в с.- х. организациях - 20,3 тыс. т, в крестьянских (фермерских) хозяйствах - 51,2 тыс. т.

В области насчитывается чуть более 10 с. - х. организаций и крестьянских (фермерских) хозяйств, специализирующихся на производстве товарного картофеля. Среди них самые крупные и успешные - AO «Картофельная Нива Орловщины» и крестьянское (фермерское) хозяйство Владимира Ивановича Стебакова, которое остается безусловным лидером отрасли по итогам последних пяти лет.

Владимиру Ивановичу Стебакову удается получать без полива урожай картофеля более 50 т/га. Под этой культурой в хозяйстве ежегодно занято от 400 до 500 га.

у Владимира Ивановича есть и помощники в картофельном бизнесе, в основном это члены его семьи: сын Геннадий, зарегистрировавший собственное крестьянско-фермерское хозяйство, специализируется также на картофелеводстве. Дочь Екатерина помогает по экономической части, ведет документооборот и решает различные финансовые задачи. C первых дней бок о бок трудится с Владимиром Ивановичем его друг и однофамилец Алексей Стебаков, помогает зять Даниил.

Семья работает на родной земле в Малой Куликовке Орловского района, здесь родился и вырос сам Владимир Иванович, здесь выросли его дети и уже подрастают внуки.

Некогда рядовое фермерское хозяйство за последние годы превратилось в одно из передовых картофелеводческих предприятий страны, в том числе за счет применения самых современных технологий производства семенного материала картофеля.

На базе хозяйства ИП Глава КФХ Стебакова В.И. планируется созда- 


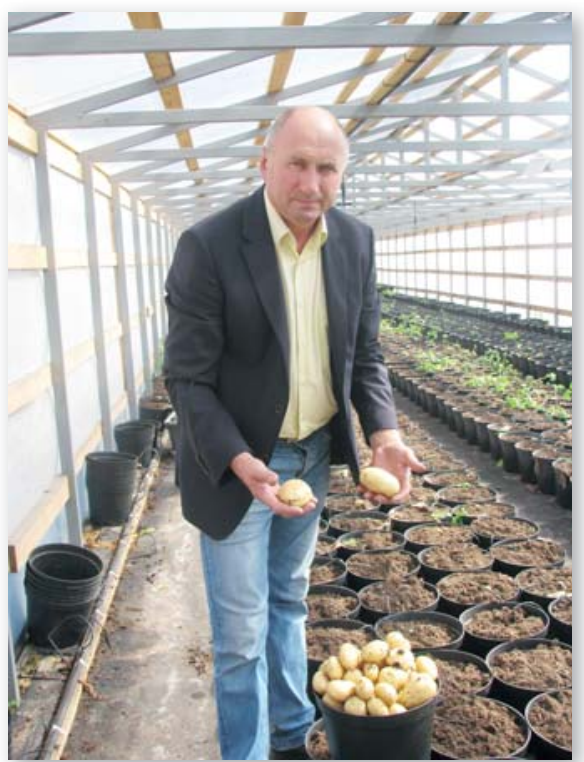

Первый опыт производства семенного материала картофеля в теплицах В.И. Стебакова

ние специализированного регионального семеноводческого центра, что позволит серьезно улучшить работу в одном из основных звеньев системы семеноводства картофеля, а именно в оригинальной его части, на основе инновационных технологий на уровне выращивания мини клубней, супер-суперэлиты, суперэлиты и элиты, применения высокоэффективных методов диагностики фитопатогенов на всех этапах.

На сегодняшний день ИП Глава КФХ Стебакова В.И. разработал про- ект и ввел в эксплуатацию две теп-

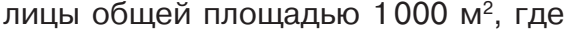
в текущем году произвели 146 тыс. тепличных мини-клубней из пробирочных растений, приобретенных у компании ООО «ФАТ-АГРО» (г. Владикавказ). Этот семенной материал сертифицирован. Во время культивации прошли апробацию в системе Россельхозцентр. Заключен договор с ВНИИКХ имени А.Г. Лорха на приобретение 10000 единиц материала in vitro сортов картофеля Жуковский ранний, Гранд, Ред Скарлетт, Ривьера на научное сопровождение технологии производства на период реализации проекта (2018-2023 годы) и договор о научном сопровождении непосредственно под руководством Юрловой Светланы Михайловны. Для хранения тепличных мини-клубней был построен отдельный склад, изолированный от источников заражения.

Также был произведен семенной материал 1 ПП (первое полевое поколение), на полностью изолированном участке, где получен чистый материал, по результатам тестирования аккредитованной лаборатории, что в дальнейшем позволяет с уверенностью производить чистый элитный семенной картофель.

В 2019 году ИП Глава КФХ Стебакова В.И. запланировал расширение, а именно, строительство еще одной тепличной конструкции, что позволит обеспечить собственное хозяйство в ближайшие пять лет элитными семенами, а также обес-

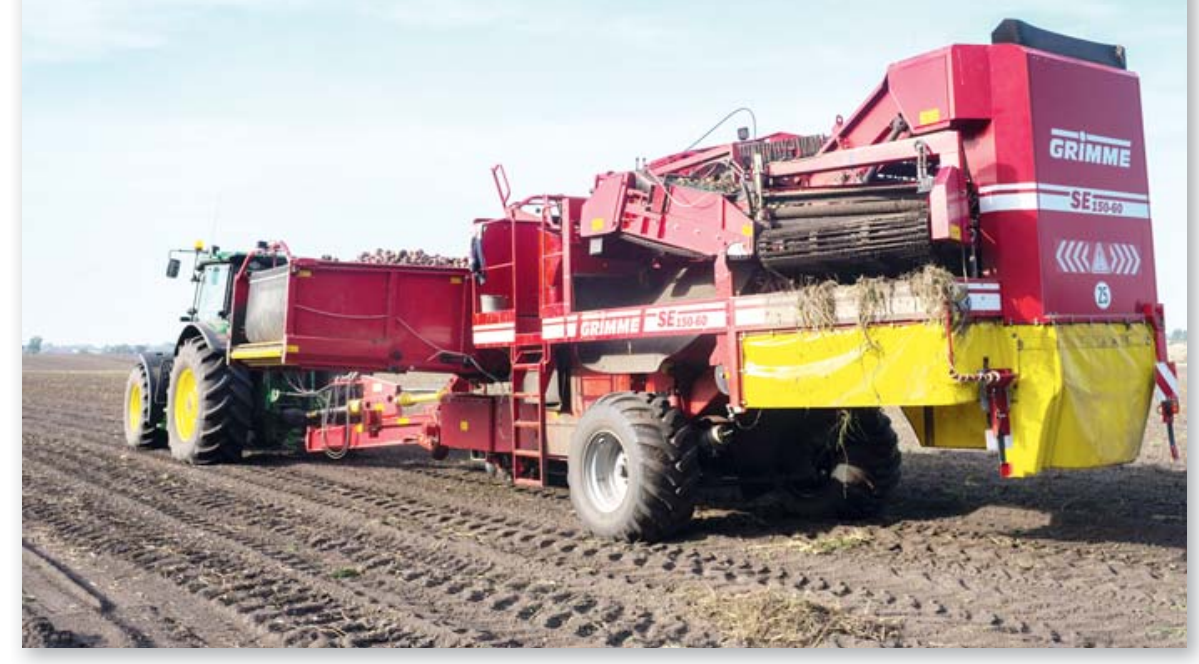

Механизированная уборка картофеля в К(Ф)Х Стебакова Владимира Ивановича печить нуждающиеся хозяйства Орловской области.

Владимир Иванович помогает местной школе и другим социальным учреждениям, полностью обеспечивая их картофелем, а также занимается благоустройством памятников и мемориалов участников Великой Отечественной войны.

Считаем, что с такими руководителями, как Стебаков Владимир Иванович, у орловского картофеля есть все надежды на хорошее будущее. Именно такой профессиональный подход и любовь к своему делу позволят возродить былую славу «орловской картошки», так любимой москвичами и южанами, закупающими в нашем регионе ежегодно тысячи тонн вкусных клубней.

\section{Библиографический список}

1.Жаров А.Н., Жарова Л.Л., Попов В.П. Современное состояние производства овощей в Российской Федерации // Вестник российского университета дружбы народов. 2008. № 1. С. 43-52.

2.Посевная площадь картофеля - Орловская область [Электронный ресурс] URL: https://сельхозпортал.рф/ analiz-posevnyh-ploshhadej/?region_id=2247\&area=12. (Дата обращения: 12.12.18).

3.Яковлева Н. А. Статистико-экономический анализ картофелепроизводства в Орловской области // Инновационная экономика: перспективы развития и совершенствования. 2013. № 3. С. 277-280.

4.Яковлева Н. А. Состояние и тенденции развития производства картофеля в Орловской области // Инновационная экономика: перспективы развития и совершенствования. 2016. № 8. С. 193-199.

5.Степанович С. В. Некоторые проблемы развития агропромышленной интеграции на основе кластерного подхода // Экономика сельского хозяйства России. 2013. № 10. С. 57-64.

\section{Об авторе}

Гуринович Ирина Александровна, заместитель директора Центра аграрных компетенций, ФГБНУ «Федеральный научный центр зернобобовых и крупяных культур». E-mail: i.gurinovich@mail.ru

Dynamics raises hopes

I.A. Gurinovich, deputy director of the centre of agrarian competences, FSBSI Federal Scientific Centre of Leguminous and Cereal Crops.E-mail: i.gurinovich@mail.ru

Summary. Information on soil and climatic conditions and potato growing in Orel region is given, which in recent years shows a high dynamics of development. Potato production is mainly concentrated in the Central and Western regions of the region, to a lesser extent - in the South-East. In the region there are more than 10 agricultural organizations and farms specializing in the production of commercial potatoes. Among them are the largest and most successful: JSC "Potato field of Orlov» and KFH Stebakov V.I. Keywords: potato growing, technology, fertilizers, import substitution, yield. 